\title{
IMPLEMENTASI JARINGAN SARAF TIRUAN DENGAN METODE BACKPROPAGATION TERHADAP BIBIT TANAMAN KARET
}

\author{
Oleh : \\ RAHMAD FAUZI \\ Dosen STKIP Tapanuli Selatan
}

\begin{abstract}
Availability of seeds is one of the critical success factors of increasing the productivity of rubber plantations, the empirical use of seeds as one component technology has made a great contribution in increasing the productivity of rubber plantations. To obtain plant materials of good quality, it is worth noting the procurement process as well as the quality standards of seeds produced, if all quality standards at every election seedlings to be planted, it is certain that the results will be planted in accordance with what had been planned as long as it is balanced with proper maintenance based technical. Artificial Neural Networks can be used to obtain information about the quality of rubber seedlings by using Backpropagation, observations and measurements of rubber seed 51 seeds were used as a sample, of 50 rubber seed of the 35 samples used as training data and 16 samples as test data, observations done by looking at the characteristics of rubber seed color, reflectivity, results marinade, long beans, broad beans and thick seeds. From the results of the training conducted by Artificial Neural Networks as many as 35 sample data by using architecture patterns 6151 obtained accuracy rate of $94.29 \%$, which means that the artificial neural network has been able to identify the quality of the rubber plant seeds, to prove the results of the training testing using a sample of 16 pieces of new data that has not been trained before, the test results showed the accuracy rate of 100\%, of the test results can be concluded that the application of Artificial Neural Networks to identify quality rubber seedlings with architectural 6151 more accurate compared to other architectures.
\end{abstract}

Kata Kunci : Jaringan Syaraf Tiruan, Backpropagation, Bibit Tanaman Karet

\section{Pendahuluan}

Ketersediaan bibit unggul merupakan salah satu faktor penentu keberhasilan peningkatan produktifitas perkebunan karet, secara empiris pemanfaatan bibit unggul sebagai salah satu komponen teknologi telah memberikan kontribusi yang besar dalam peningkatan produktifitas kebun. Untuk mendapatkan bahan tanaman yang bermutu baik, maka perlu diperhatikan proses pengadaan serta standar mutu benih yang dihasilkan, jika semua standar mutu pada setiap pemilihan bibit yang akan ditanam, dapat dipastikan bahwa hasil yang akan ditanam sesuai dengan yang telah direncanakan asalkan diimbangi dengan pemeliharaan yang tepat berdasarkan teknisnya.Jaringan Syaraf Tiruan dapat dipergunakan untuk memperoleh informasi kualitas bibit tanaman karet dengan menggunakan metode Backpropagation, sehingga para petani tanaman karet lebih mudah mengetahui kualitas dari bibit yang akan ditanam.

\section{Konsep Dasar Jaringan Syaraf Tiruan}

Jaringan Syaraf Tiruan terdiri dari beberapa neuron, neuron tersebut saling berhubungan dengan neuron-neuron yang lain. Neuron-neuron tersebut akan mentransformasikan informasi yang diterima melalui sambungan keluarnya menuju neuron-neuron yang lain, hubungan ini disebut dengan bobot pada Jaringan Syaraf Tiruan. Selanjutnya informasi tersebut akan disimpan pada bobot dengan nilai tertentu. Gambar dibawah ini 
menunjukkan struktur neuron pada Jaringan Syaraf Tiruan.

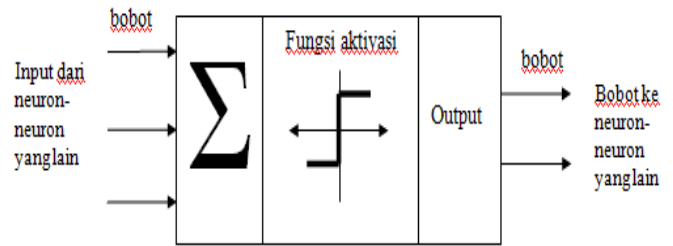

Gambar 2.1. Struktur Neuron Jaringan Syaraf

Tiruan

Dari gambar 2.1. dapat dilihat bahwa neuron buatan sangat mirip dengan sel neuron biologis. Neuron-neuron buatan dan neuron-neuron biologis bekerja dengan cara yang sama. Informasi dikirim ke neuron dengan bobot kedatangan tertentu, selanjutnya akan diproses suatu fungsi perambatan yang akan menjumlahkan nilai bobot yang datang. Kemudian hasil dari penjumlahan tersebut akan dibandingkan dengan nilai threshold melalui fungsi aktivasi dari setiap neuron.

\subsection{Proses Pembelajaran Jaringan Syaraf Tiruan}

Jaringan Syarat Tiruan akan meniru cara kerja otak untuk belajar, seperti otak manusia Jaringan Syaraf Tiruan juga mempunyai neuron-neuron dan denrit, yang membedakan antara otak sesungguhnya bahwa Jaringan Syaraf Tiruan memiliki sturuktur yang tidak bisa diubah, dibangun oleh sejumlah neuron, dan mempunyai nilai tertentu yang menunjukkan seberapa besar koneksi antara neuron. Hal yang berubah selama proses pembelajaran adalah nilai-nilai bobot, ketika informasi yang diberikan oleh neuron sampai maka nilai bobot tersebut akan bertambah, akan tetapi jika informasi tidak disampaikan oleh sebuah neuron ke neuron yang lain maka nilai bobotnya akan dikurangi. Ketika pada masa pembelajaran dilakukan pada input yang berbeda, maka nilai akan diubah sehingga nilai-nilai tersebut cukup seimbang. Jika nilai tersebut sudah tercapai maka itu menandakan bahwa setiap input telah berhubungan dengan output yang diaharapkan.

\subsection{Arsitektur Backpropagation}

Algoritma Backpropagation terdiri dari banyak lapisan (multilayes neural network). Unit-unit yang berada pada lapisan input (input layers) terhubung dengan kepada unit yang berada di lapisan tersembunyi (hidden layers). Dan unit-unit yang berada dilapisan tersembunyi terhubung ke unit-unit yang berada di lapisan output (output layers).

\subsection{Algoritma Backpropagation}

Alur kerja metoda Backpropagation dapat dilihat pada gambar 2.4 .

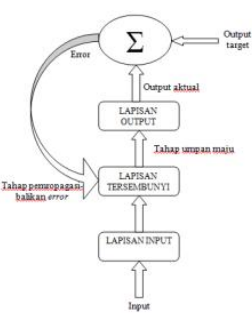

\section{Gambar 2.2. Alur Kerja Jaringan Backpropagation}

Dari gambar 2.4. dapat diketahui bahwa, Jaringan Saraf Tiruan perlu belajar terlebih dahulu, yang dimulai memasukkan sekumpulan contoh pelatihan ke dalam jaringan, atau disebut juga dengan set pelatihan, set pelatihan tersebut dapat digambarkan dengan sebuah vector feature atau disebut juga dengan vector input, yang diasosiasikan kepada output untuk dijadikan sebagai target pelatihannya, pelatihan-pelatihan yang dilaksanakan mempunyai maksus agar jaringan Syaraf Tiruan dapat beradabtasi kepada karakteristik dari contoh-contoh set pelatihan dengan melakukan penguabahan, peng-update-an bobot-bobot yang berada di dalam jaringan tersebut. 


\subsection{Fungsi Aktivasi pada Backpropagation}

Pada metode backpropagation ada pilihan fungsi aktivasi yang digunakan, fungsi aktivasi yang digunakan harus memenuhi persyaratan, yaitu : kontinu, terdiferensial dengan mudah dan merupakan fungsi yang tidak turun. Fungsi yang sering digunakan dan juga fungsi yang sudah memenuhi persyaratan yang disebutkan diatas menurut (Jong Jek Siang,2009) adalah :

1. Fungsi sigmoid biner

Fungsi sigmoid biner memiliki range $(0,1)$.

$$
\begin{gathered}
f(x)=\frac{1}{1+e^{-x}} \\
\text { dengan turunan } \\
f^{\prime}(x)=f(x)(1-f(x))
\end{gathered}
$$

Grafik fungsinya dapat dilihat pada gambar 2.5.

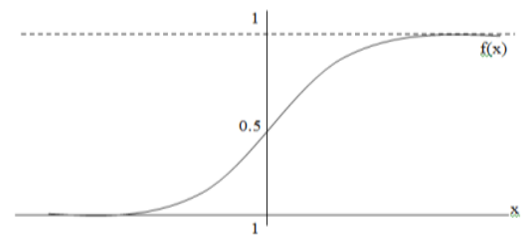

Gambar 2.3. Grafik Fungsi Sigmoid Biner

Selain dari fungsi sigmoid biner, fungsi lain yang sering dipakai adalah fungsi sigmoid bipolar, fungsi ini mirip dengan fungsi sigmoid biner, yang membedakannya adalah rangenya, jika di fungsi sigmoid biner rangenya $(0,1)$ maka range fungsi sigmoid bipolar adalah $(-1,1)$.

$$
\begin{gathered}
f(x)=\frac{2}{1+e^{-x}}-1 \\
\text { dengan turunan } \\
f^{\prime}(x)=\frac{(1+f(x))(1-f(x))}{2}
\end{gathered}
$$

Grafik fungsinya dapat dilihat pada gambar 2.6.

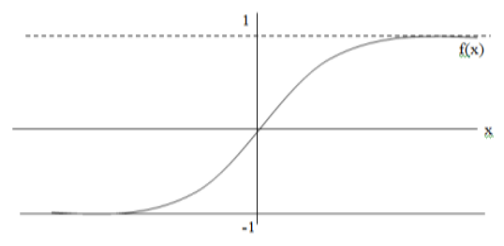

Gambar 2.4. Grafik Fungsi Sigmoid Bipolar

Nilai maksimum dari Fungsi sigmoid adalah $=$ 1. Untuk pola yang targetnya $>1$, pola masukan dan keluaran harus terlebih dahulu ditransformasikan sehingga semua polanya memiliki range yang sama seperti fungsi sigmoid yang dipakai. Alternatif lain adalah menggunakan fungsi sigmoid hanya layar yang bukan layar keluaran. Pada layar keluaran, fungsi aktivasi yang dipakai adalah fungsi identitas : $f(x)=x$.

Algoritma pelatihan Backpropagation dengan sebuah lapisan tersembunyi (hidden layer).

\section{MetodePenelitian}

Penelitian ini dimulai dengan melakukan identifikasi masalah, kemudian dilakukan pencarian dan pengumpulan data yang akan digunakan pada tahapan pelatihan dan pengujian data. Kerangka kerja penelitian dapat dilihat pada gambar di bawah ini :

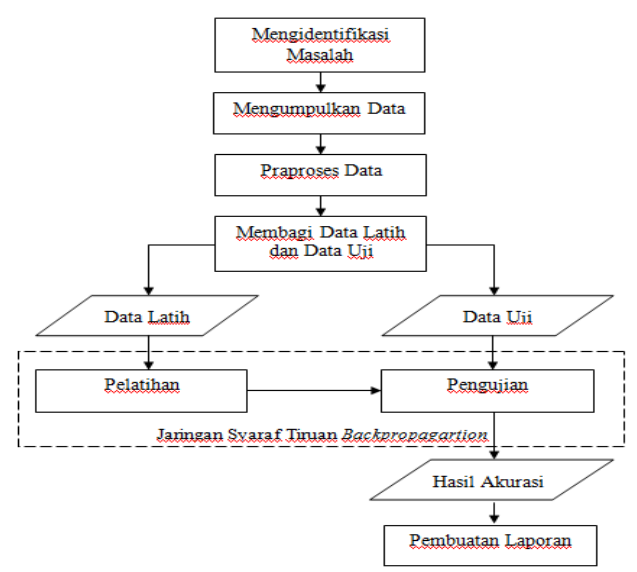

Gambar 3.1. Grafik Fungsi Sigmoid Bipolar 


\section{Hasil dan Pembahasan}

\subsection{Analisa dan perancangan}

Sampel pada penelitian ini adalah sebanyak 51 buah sampel, untuk data pelatihan digunakan 35 data yang sudah diamati dari biji karet sedangkan data uji digunakan 21 data dari biji karet yang sudah diamati dari semua sampel yang dijadikan penelitian ini adalah dari jenis GT1, PB260, RRIC100 DAN AVROS2037 pengambilan sampel dilakukan tanpa menyeleksi kualitas dari biji tersebut, Berikut ini data hasil pengamatan dan pengukuran biji karet berdasarkan ciri-ciri yang sudah diterangkan di awal, penulis mendapatkan data seperti yang terlihat pada tabel 4.4 .

Tabel 4.1. Data Hasil Pengamatan

\begin{tabular}{|c|c|c|c|c|c|c|c|}
\hline SP & WRN & DP & HR & PJ & LB & TB & HK \\
\hline 1 & 8.5 & 10 & 10 & 2.2 & 1.8 & 1.4 & 1 \\
\hline 2 & 10 & 10 & 10 & 2.2 & 1.8 & 1.5 & 1 \\
\hline 3 & 7.5 & 10 & 10 & 2 & 1.7 & 1.3 & 1 \\
\hline 4 & 8.5 & 10 & 5 & 2.1 & 1.6 & 1.5 & 0.5 \\
\hline 5 & 10 & 10 & 10 & 2.1 & 1.6 & 1.3 & 1 \\
\hline 6 & 8.5 & 5 & 10 & 2.1 & 1.8 & 1.4 & 1 \\
\hline 7 & 10 & 10 & 10 & 1.9 & 1.6 & 1.4 & 1 \\
\hline 8 & 10 & 10 & 10 & 2.2 & 1.8 & 1.4 & 1 \\
\hline 9 & 10 & 10 & 5 & 2.1 & 1.6 & 1.4 & 0.5 \\
\hline 10 & 10 & 10 & 10 & 2.2 & 1.7 & 1.4 & 1 \\
\hline 11 & 7.5 & 10 & 10 & 2.3 & 2.1 & 1.6 & 0.5 \\
\hline 12 & 7.5 & 10 & 10 & 2.2 & 2.1 & 1.6 & 0.5 \\
\hline 13 & 5 & 5 & 10 & 2.3 & 2.1 & 1.6 & 0.5 \\
\hline 14 & 5 & 5 & 10 & 2.3 & 2 & 1.5 & 0.5 \\
\hline 15 & 8.5 & 10 & 10 & 2.3 & 2 & 1.7 & 0.5 \\
\hline 16 & 7.5 & 5 & 10 & 2.2 & 2 & 1.6 & 0.5 \\
\hline 17 & 5 & 10 & 5 & 2.1 & 2 & 1.5 & 0.5 \\
\hline 18 & 5 & 10 & 5 & 2.1 & 1.9 & 1.5 & 0.5 \\
\hline 19 & 7.5 & 10 & 10 & 2.2 & 1.9 & 1.5 & 0.5 \\
\hline 20 & 5 & 10 & 10 & 2.1 & 1.9 & 1.5 & 0.5 \\
\hline 21 & 10 & 10 & 5 & 2.5 & 2.1 & 1.7 & 0.5 \\
\hline 22 & 10 & 10 & 10 & 2.6 & 2.2 & 1.8 & 1 \\
\hline
\end{tabular}

Tabel 4.1. Data Hasil Pengamatan (Lanjutan)

\begin{tabular}{|c|l|l|l|l|l|l|l|}
\hline SP & WRN & DP & HR & PJ & LB & TB & HK \\
\hline
\end{tabular}

\begin{tabular}{|c|c|c|c|c|c|c|c|}
23 & 7.5 & 10 & 10 & 2.8 & 2.1 & 1.9 & 0.5 \\
\hline 24 & 5 & 5 & 10 & 2.7 & 2.1 & 1.9 & 0.5 \\
\hline 25 & 10 & 10 & 10 & 2.6 & 2.2 & 1.8 & 1 \\
\hline 18 & 5 & 10 & 5 & 2.1 & 1.9 & 1.5 & 0.5 \\
\hline 19 & 7.5 & 10 & 10 & 2.2 & 1.9 & 1.5 & 0.5 \\
\hline 20 & 5 & 10 & 10 & 2.1 & 1.9 & 1.5 & 0.5 \\
\hline 21 & 10 & 10 & 5 & 2.5 & 2.1 & 1.7 & 0.5 \\
\hline 22 & 10 & 10 & 10 & 2.6 & 2.2 & 1.8 & 1 \\
\hline 31 & 10 & 10 & 5 & 2.5 & 2.2 & 1.9 & 0.5 \\
\hline 32 & 8.5 & 10 & 10 & 2.2 & 2 & 1.8 & 1 \\
\hline 33 & 5 & 5 & 10 & 2.3 & 2.3 & 1.9 & 0.5 \\
\hline 34 & 8.5 & 10 & 10 & 2.4 & 2.1 & 1.9 & 1 \\
\hline 35 & 5 & 5 & 10 & 2.4 & 2.1 & 1.6 & 0.5 \\
\hline 36 & 8.5 & 10 & 10 & 2.4 & 2.1 & 1.8 & 1 \\
\hline 37 & 10 & 10 & 10 & 2.7 & 2.3 & 1.9 & 1 \\
\hline 38 & 10 & 10 & 10 & 2.6 & 2.2 & 1.9 & 1 \\
\hline 39 & 8.5 & 10 & 10 & 2.3 & 2.2 & 1.8 & 1 \\
\hline 40 & 10 & 10 & 5 & 2.4 & 2.2 & 1.8 & 0.5 \\
\hline 41 & 8.5 & 5 & 5 & 2.4 & 2.2 & 1.7 & 0.5 \\
\hline 42 & 5 & 5 & 5 & 2.3 & 2.2 & 1.7 & 0.5 \\
\hline 43 & 5 & 5 & 5 & 2.6 & 2.4 & 1.9 & 0.5 \\
\hline 44 & 7.5 & 5 & 10 & 2.5 & 2.3 & 1.8 & 0.5 \\
\hline 45 & 5 & 5 & 10 & 2.4 & 2.4 & 1.8 & 0.5 \\
\hline 46 & 5 & 5 & 5 & 2.6 & 2.3 & 1.8 & 0.5 \\
\hline 47 & 7.5 & 5 & 10 & 2.2 & 1.9 & 1.6 & 0.5 \\
\hline 48 & 5 & 5 & 5 & 2.6 & 2.3 & 1.9 & 0.5 \\
\hline 49 & 7.5 & 5 & 5 & 2.3 & 2.1 & 1.6 & 0.5 \\
\hline 50 & 5 & 5 & 5 & 2.5 & 2.3 & 2 & 0.5 \\
\hline 51 & 7.5 & 5 & 5 & 2.4 & 2.2 & 1.8 & 0.5 \\
\hline
\end{tabular}

Dari data hasil pengamatan pada tabel 4.4. kemudian data tersebut ditransformasi ke dalam range $[0,1]$ menggunakan rumus transformasi [14] berikut ini contoh perhitungan transformasi data hasil pengamatan dan pengukuran biji karet:

$$
X_{1}=\frac{0,8(8,5-0,5)}{10-0,5}+0,1=0,77
$$

Dari hasil semua perhitungan yang telah dilakukan didapat hasil seperti pada tabel 4.5 , untuk perhitungan 
manual dari semua data dapat dilihat pada lembaran lampiran.

Tabel 4.2. Data Hasil Transformasi Pengamatan Biji Karet

\begin{tabular}{|c|c|c|c|c|c|c|c|}
\hline SP & WRN & DP & HR & PJ & LB & TB & HK \\
\hline 1 & 0.77 & 0.90 & 0.90 & 0.24 & 0.21 & 0.18 & 1 \\
\hline 2 & 0.90 & 0.90 & 0.90 & 0.24 & 0.21 & 0.18 & 1 \\
\hline 3 & 0.69 & 0.90 & 0.90 & 0.23 & 0.20 & 0.17 & 1 \\
\hline 4 & 0.77 & 0.90 & 0.48 & 0.23 & 0.19 & 0.18 & 0.5 \\
\hline 5 & 0.90 & 0.90 & 0.90 & 0.23 & 0.19 & 0.17 & 1 \\
\hline 6 & 0.77 & 0.48 & 0.90 & 0.23 & 0.21 & 0.18 & 1 \\
\hline 7 & 0.90 & 0.90 & 0.90 & 0.22 & 0.19 & 0.18 & 1 \\
\hline 8 & 0.90 & 0.90 & 0.90 & 0.24 & 0.21 & 0.18 & 1 \\
\hline 9 & 0.90 & 0.90 & 0.48 & 0.23 & 0.19 & 0.18 & 0.5 \\
\hline 10 & 0.90 & 0.90 & 0.90 & 0.24 & 0.20 & 0.18 & 1 \\
\hline 11 & 0.69 & 0.90 & 0.90 & 0.25 & 0.23 & 0.19 & 0.5 \\
\hline 12 & 0.69 & 0.90 & 0.90 & 0.24 & 0.23 & 0.19 & 0.5 \\
\hline 13 & 0.48 & 0.48 & 0.90 & 0.25 & 0.23 & 0.19 & 0.5 \\
\hline 14 & 0.48 & 0.48 & 0.90 & 0.25 & 0.23 & 0.18 & 0.5 \\
\hline 15 & 0.77 & 0.90 & 0.90 & 0.25 & 0.23 & 0.20 & 0.5 \\
\hline 16 & 0.69 & 0.48 & 0.90 & 0.24 & 0.23 & 0.19 & 0.5 \\
\hline
\end{tabular}

Tabel 4.5. Data Hasil Transformasi Pengamatan Biji Karet (Lanjutan)

\begin{tabular}{|c|c|c|c|c|c|c|c|}
\hline SP & WRN & DP & HR & PJ & LB & TB & HK \\
\hline 17 & 0.48 & 0.90 & 0.48 & 0.23 & 0.23 & 0.18 & 0.5 \\
\hline 18 & 0.48 & 0.90 & 0.48 & 0.23 & 0.22 & 0.18 & 0.5 \\
\hline 19 & 0.69 & 0.90 & 0.90 & 0.24 & 0.22 & 0.18 & 0.5 \\
\hline 20 & 0.48 & 0.90 & 0.90 & 0.23 & 0.22 & 0.18 & 0.5 \\
\hline 21 & 0.90 & 0.90 & 0.48 & 0.27 & 0.23 & 0.20 & 0.5 \\
\hline 22 & 0.90 & 0.90 & 0.90 & 0.28 & 0.24 & 0.21 & 1 \\
\hline 23 & 0.69 & 0.90 & 0.90 & 0.29 & 0.23 & 0.22 & 0.5 \\
\hline 24 & 0.48 & 0.48 & 0.90 & 0.29 & 0.23 & 0.22 & 0.5 \\
\hline 25 & 0.90 & 0.90 & 0.90 & 0.28 & 0.24 & 0.21 & 1 \\
\hline 26 & 0.77 & 0.90 & 0.90 & 0.28 & 0.24 & 0.21 & 1 \\
\hline 27 & 0.48 & 0.48 & 0.90 & 0.29 & 0.25 & 0.22 & 0.5 \\
\hline 28 & 0.69 & 0.90 & 0.90 & 0.29 & 0.26 & 0.20 & 0.5 \\
\hline 29 & 0.90 & 0.90 & 0.90 & 0.29 & 0.26 & 0.21 & 1 \\
\hline 30 & 0.77 & 0.90 & 0.90 & 0.27 & 0.23 & 0.19 & 1 \\
\hline 31 & 0.90 & 0.90 & 0.48 & 0.27 & 0.24 & 0.22 & 0.5 \\
\hline 32 & 0.77 & 0.90 & 0.90 & 0.24 & 0.23 & 0.21 & 1 \\
\hline 33 & 0.48 & 0.48 & 0.90 & 0.25 & 0.25 & 0.22 & 0.5 \\
\hline 34 & 0.77 & 0.90 & 0.90 & 0.26 & 0.23 & 0.22 & 1 \\
\hline
\end{tabular}

\begin{tabular}{|c|c|c|c|c|c|c|c|}
\hline 35 & 0.48 & 0.48 & 0.90 & 0.26 & 0.23 & 0.19 & 0.5 \\
\hline 36 & 0.77 & 0.90 & 0.90 & 0.26 & 0.23 & 0.21 & 1 \\
\hline 37 & 0.90 & 0.90 & 0.90 & 0.29 & 0.25 & 0.22 & 1 \\
\hline 38 & 0.90 & 0.90 & 0.90 & 0.28 & 0.24 & 0.22 & 1 \\
\hline 39 & 0.77 & 0.90 & 0.90 & 0.25 & 0.24 & 0.21 & 1 \\
\hline 40 & 0.90 & 0.90 & 0.48 & 0.26 & 0.24 & 0.21 & 0.5 \\
\hline 41 & 0.77 & 0.48 & 0.48 & 0.26 & 0.24 & 0.20 & 0.5 \\
\hline 42 & 0.48 & 0.48 & 0.48 & 0.25 & 0.24 & 0.20 & 0.5 \\
\hline 43 & 0.48 & 0.48 & 0.48 & 0.28 & 0.26 & 0.22 & 0.5 \\
\hline 44 & 0.69 & 0.48 & 0.90 & 0.27 & 0.25 & 0.21 & 0.5 \\
\hline 45 & 0.48 & 0.48 & 0.90 & 0.26 & 0.26 & 0.21 & 0.5 \\
\hline 46 & 0.48 & 0.48 & 0.48 & 0.28 & 0.25 & 0.21 & 0.5 \\
\hline 47 & 0.69 & 0.48 & 0.90 & 0.24 & 0.22 & 0.19 & 0.5 \\
\hline 48 & 0.48 & 0.48 & 0.48 & 0.28 & 0.25 & 0.22 & 0.5 \\
\hline 49 & 0.69 & 0.48 & 0.48 & 0.25 & 0.23 & 0.19 & 0.5 \\
\hline 50 & 0.48 & 0.48 & 0.48 & 0.27 & 0.25 & 0.23 & 0.5 \\
\hline 51 & 0.69 & 0.48 & 0.48 & 0.26 & 0.24 & 0.21 & 0.5 \\
\hline
\end{tabular}

\subsection{Arsitektur Jaringan Syaraf Tiruan}

Arsitektur Jaringan Syaraf Tiruan yang digunakan pada penelitian ini adalah multilayer net, dengan algoritma Backpropagation, yang terdiri dari :

a. Lapisan masukan (input) dengan $6 \operatorname{simpul}\left(X_{1}, X_{2}, X_{3}\right.$, $X_{4}, X_{5}$, dan $\left.X_{6}\right)$

b. Lapisan tersembunyi (hidden) dengan jumlah simpul yang ditentukan oleh pengguna $\left(y_{1}, y_{2}\right)$.

c. Lapisan keluaran (output) dengan 1 simpul (z)

Untuk lebih jelasnya dapat dilihat pada gambar 4.2.

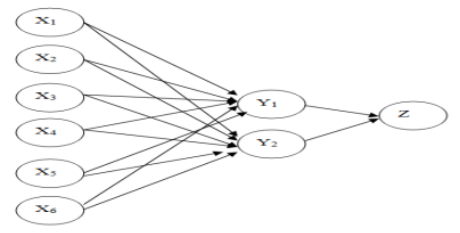

Gambar 4.2. Arsitektur Jaringan Syaraf Tiruan Untuk Identifikasi Kualitas Bibit Tanaman Karet 
Gambar 4.2. adalah rancangan model arsitektur Jaringan Syaraf Tiruan dengan menggunakan jaringan multilayer, berikut ini keterangan gambar 4.2.

$X_{1} \quad=$ Warna

$X_{2} \quad=$ Daya Pantul

$X_{3} \quad=$ Hasil Rendaman

$X_{4} \quad=$ Panjang Biji

$X_{5} \quad=$ Lebar Biji

$X_{6} \quad=$ Tebal Biji

$Y_{1}-Y_{2}=$ Banyaknya lapisan tersembunyi (Hidden

Layer)

Z = Output (Hasil/Kesimpulan)

Jaringan Syaraf Tiruan yang akan dibangun adalah dengan menggunakan algoritma Backpropagation dengan fungsi aktivasi sigmoid, fungsi aktivasi sigmoid ini yang akan dipakai untuk proses perhitungan terhadap nilai aktual output pada hidden layer dan perhitungan nilai aktual pada output layer.

\subsection{Penerapan Jaringan Syaraf Tiruan}

Pada tahapan ini data yang didapat dari hasil pengamatan biji karet tersebut akan diterapkan pada Jaringan Syaraf Tiruan dengan Algoritma Backpropagation sedangkan aktivasi yang digunakan pada perhitungan ini adalah fungsi aktivasi sigmoid

Berikut tahapan-tahapan yang akan dilakukan:

1. Tahapan Inisialisasi, merupakan tahapan untuk menentukan nilai Input, Output, Learning rate, Epoch,error dan nilai data lainnya.

2. Tahapan Aktivasi, merupakan proses perhitungan terhadap nilai aktual output pada hidden layer dan menghitung nilai aktual pada output layer.

3. Weight training, merupakan proses perhitungan nilai error gradient pada output layer dan menghitung nilai error gradient pada hidden layer.

4. Iterasi, merupakan tahapan akhir dalam pengujian, apabila masih terjadi error yang diharapkan belum ditemukan maka kembali ke tahapan aktivasi.
Berikut ini Contoh perhitungan manual untuk menghitung nilai pelatihan dengan Jaringan Syaraf Tiruan untuk mengidentifikasi kualitas bibit tanaman karet. Perhitungan Jaringan Syaraf Tiruan secara manual dimulai dengan menginisialisasi bobot awal, bobot ini yang akan menghubungkan simpul-simpul pada input layer, hidden layer dan Output sesuai dengan arsitektur Backpropagation pada gambar 4.2. yang terdiri dari 6 buah variabel input vector $x$, dan satu target $t$ yaitu :

$X_{1} \quad=$ Warna

$X_{2} \quad=$ Daya Pantul

$X_{3} \quad=$ Hasil Rendaman

$X_{4} \quad=$ Panjang Biji

$X_{5} \quad=$ Lebar Biji

$X_{6} \quad=$ Tebal Biji

$T \quad=$ Hasil $/$ Kesimpulan

Berikut ini tabel nilai input dan target data hasil pengamatan biji karet pada sampel ke 1 :

Tabel 4.6. Nilai Input Data dan Target

\begin{tabular}{|c|c|c|c|c|c|c|}
\hline $\mathrm{X}_{1}$ & $\mathrm{X}_{2}$ & $\mathrm{X}_{3}$ & $\mathrm{X}_{4}$ & $\mathrm{X}_{5}$ & $\mathrm{X}_{6}$ & $\mathrm{~T}$ \\
\hline 8.5 & 10 & 10 & 2.2 & 1.8 & 1.4 & 1 \\
\hline
\end{tabular}

Data tersebut kemudian ditransformasi dengan menggunakan rumus transformasi, dari hasil pengukuran semua data secara manual didapat nilai $\max =10$ sedangkan nilai $\min =0,5$ berikut hasil perhitungan transformasi data dari nilai tabel 4.7.

$$
\begin{aligned}
& X_{1}=\frac{0,8(8,5-0,5)}{10-0,5}+0,1=0,77 \\
& X_{2}=\frac{0,8(10-0,5)}{10-0,5}+0,1=0,90 \\
& X_{3}=\frac{0,8(10-0,5)}{10-0,5}+0,1=0,90 \\
& X_{4}=\frac{0,8(2,2-0,5)}{10-0,5}+0,1=0,24 \\
& X_{5}=\frac{0,8(1,8-0,5)}{10-0,5}+0,1=0,21 \\
& X_{6}=\frac{0,8(1,4-0,5)}{10-0,5}+0,1=0,18
\end{aligned}
$$


Hasil dari perhitungan transformasi dapat dilihat pada pada tabel 4.8 .

Tabel 4.7. Data Hasil Transformasi

\begin{tabular}{|c|c|c|c|c|c|c|}
\hline $\mathrm{X}_{1}$ & $\mathrm{X}_{2}$ & $\mathrm{X}_{3}$ & $\mathrm{X}_{4}$ & $\mathrm{X}_{5}$ & $\mathrm{X}_{6}$ & $\mathrm{~T}$ \\
\hline 0.77 & 0.90 & 0.90 & 0.24 & 0.21 & 0.18 & 1 \\
\hline
\end{tabular}

Setelah hasil transformasi diketahui kemudian langkah selanjunya adalah menetapkan nilai input, nilai target, learning rate $(\alpha)$, dan epoch, Berikut ini analisa masalah dengan menggunakan arsitektur 6-2-1 :

1. Tahap Inisialisasi

a. Diketahui :

$$
\begin{array}{ll}
x_{1} & =0,77 \\
x_{2} & =0,90 \\
x_{3} & =0,90 \\
x_{4} & =0,24 \\
x_{5} & =0,21 \\
x_{6} & =0,18 \\
t & =1
\end{array}
$$

learning rate $(\alpha) \quad=0,1$

b. Berikan nilai bobot $(v)$ dengan nilai acak pada dari input layer ke hidden layer:

Tabel 4.8. Bobot Dari Input Layer Ke Hidden Layer

\begin{tabular}{|c|c|c|}
\hline & $Y_{I}$ & $Y_{2}$ \\
\hline$V_{l}$ & 3.8723 & -0.1830 \\
\hline$V_{2}$ & 3.6817 & 3.3870 \\
\hline$V_{3}$ & 0.5583 & 1.5139 \\
\hline$V_{4}$ & -29.9790 & 8.0223 \\
\hline$V_{5}$ & -8.8134 & -31.5025 \\
\hline$V_{6}$ & -0.9354 & -30.1051 \\
\hline
\end{tabular}

c. Berikan nilai bobot $(W)$ dari hidden layer ke output dengan nilai acak.

Tabel 4.9. Bobot Dari Hidden Layer Ke Output Layer

\begin{tabular}{|c|c|}
\hline & $Z$ \\
\hline$W_{1}$ & -0.7538 \\
\hline$W_{2}$ & -0.589 \\
\hline
\end{tabular}

Tahap Iterasi 1 a. Hitung keluaran aktual output tiap node pada hidden layer

$$
\begin{aligned}
Y 1= & X_{1} * V_{11}+X_{2} * V_{21}+X_{3} * V_{31}+X_{4} * V_{41}+X_{5} * V_{51}+X_{6} * V_{61} \\
= & 0,77 * 3.8723+0,90 * 3.6817+0,90 * 0.5583+0,24 * \\
& -29.9790+0,21 *-8.8134+0,18 *-0.9354 \\
= & -2,488 \\
= & \text { Sigmoid }[-2,488] \\
& \frac{1}{1+e^{(-2,488)}}=0,923 \\
Y 2= & X_{1} * V_{12}+X_{2} * V_{22}+X_{3} * V_{32}+X_{4} * V_{42}+X_{5} * V_{52}+X_{6} * V_{62} \\
= & 0,77 * 0.1830+0,90 * 3.3870+0,90 * 1.5139+0,24 * \\
& 8.0223+0,21 *-31.5025+0,18 *-30.1051 \\
= & -5,671 \\
= & \text { Sigmoid }[-5.671] \\
& 1 \\
\hline 1+e & (-5,671)
\end{aligned}
$$

b. Hitung keluaran aktual output tiap node pada output layer

$$
\begin{aligned}
& Z=Y_{1} * W_{11}+Y_{2} * W_{21} \\
&=0,923 *-0,7538+0,997 * 0,589 \\
&=-1,2830 \\
&=\text { Sigmoid }[-1,2830] \\
& \frac{1}{1+e^{(-1.2830)}}=0,7830
\end{aligned}
$$

Menghitung error pada output layer dan error pada hidden layer

1. Hitung error pada output layer

$$
\begin{aligned}
\operatorname{Err} Z & =Z^{*}(\alpha-Z) *(T-Z) \\
& =0,7830 *(0,1-0,7830) *(1-0,7830) \\
& =-0,1161
\end{aligned}
$$

2. Hitung error pada hidden layer

$$
\begin{aligned}
\operatorname{Err} Y 1= & Y 1 *(\alpha-Y 1) *\left(\operatorname{Err} Z * W_{11}\right) \\
& =0,923 *(0,1-0,923) *(-0,1161 *-0,7538) \\
& =-0,0665
\end{aligned}
$$

$$
\begin{aligned}
\operatorname{Err} Y 2= & Y 2 *(\alpha-Y 2) *\left(\operatorname{Err} Z * W_{21}\right) \\
& =0,997 *(0,1-0,997) *(-0,1161 * 0,589) \\
& =-0,0611
\end{aligned}
$$


3. Hitung bobot baru

Hitung bobot baru pada hidden layer

$V_{11} \quad=V_{11}+\alpha^{*} \operatorname{Err} Y 1 * X_{1}$

$=3.8723+0,1 *_{-} 0,0665 * 0,77$

$=3,8672$

$V_{12} \quad=V_{12}+\alpha * \operatorname{Err} Y 2 * X_{1}$

$=-0.183+0,1 *-0,0611 * 0,77$

$=-0,1877$

$V_{21} \quad=V_{21}+\alpha * \operatorname{Err} Y 1 * X_{2}$

$=3.6817+0,1 *-0,0665 * 0,90$

$=3,6757$

$V_{22}=V_{22}+\alpha * \operatorname{Err} Y 2 * X_{2}$

$=3.387+0,1 *-0,0611 * 0,90$

$=3,3815$

$V_{31}=V_{31}+\alpha * \operatorname{Err} Y 1 * X_{3}$

$=0.5583+0,1 *_{-} 0,0665 * 0,90$

$=0,5523$

$V_{32}=V_{32}+\alpha * \operatorname{Err} Y 2 * X_{3}$

$=1.5139+0,1 *-0,0611 * 0,90$

$=1,5084$

$V_{41} \quad=V_{41}+\alpha^{*} \operatorname{Err} Y 1 * X_{4}$

$=-29.979+0,1 *-0,0665 * 0,24$

$=-29,9806$

$V_{42}=V_{42}+\alpha^{*} \operatorname{Err} Y 2 * X_{4}$

$=8.0223+0,1 *-0,0611 * 0,24$

$=8,0208$

$V_{51} \quad=V_{51}+\alpha * \operatorname{Err} Y 1 * X_{5}$

$=-8.8134+0,1 *_{-} 0,0665 * 0,21$

$=-8,8148$

$V_{52} \quad=V_{52}+\alpha * \operatorname{Err} Y 2 * X_{5}$

$=-31.5025+0,1 *-0,0611 * 0,21$

$=0,4019$

$V_{61} \quad=V_{61}+\alpha^{*} \operatorname{Err} Y 1^{*} X_{6}$

$=-0.9354+0,1 *-0,0665 * 0,18$

$=0,1820$

$V_{62} \quad=V_{62}+\alpha * \operatorname{Err} Y 2 * X_{6}$

$=-30.1051+0,1 *_{-} 0,0611 * 0,19$

$$
=1,9838
$$

Hitung bobot baru pada output layer

$$
\begin{aligned}
W_{11} \quad & W_{11}+\alpha * \operatorname{Err} Z * Y_{1} \\
& =-0,7538+0,1 *-0,1161 * 0,923 \\
& =-0,7654 \\
W_{21} \quad & =W_{21}+\alpha * \operatorname{Err} Z * Y_{2} \\
& =-0,589+0,1 *-0,1161 * 0,997 \\
& =-0,6006
\end{aligned}
$$

Dari hasil perhitungan di atas dapat kita lihat bahwa penggunaan Jaringan Syaraf Tiruan dengan metode Backpropagation dapat digunakan untuk mengidentifikasi kualitas bibit tanaman karet berdasarkan warna, daya pantul, hasil rendaman, panjang biji, lebar biji dan tebal biji, hal ini dapat ditunjukkan dengan melihat output layer (nilai Z), dari hasil perhitungan data di atas maka dapat dihasilkan bobot baru pada hidden layer seperti pada tabel 4.11.

Tabel 4.10. Hasil Bobot Baru Pada Hidden Layer

\begin{tabular}{|c|c|}
\hline \multicolumn{2}{|c|}{ Bobot Baru pada Hidden Layer } \\
\hline$\Delta V_{11}$ & 3.8672 \\
\hline$\Delta V_{12}$ & -0.1877 \\
\hline$\Delta V_{21}$ & 3.6757 \\
\hline$\Delta V_{22}$ & 3.3815 \\
\hline$\Delta V_{31}$ & 0.5523 \\
\hline$\Delta V_{32}$ & 1.5084 \\
\hline$\Delta V_{41}$ & -29.9806 \\
\hline$\Delta V_{42}$ & 8.0208 \\
\hline$\Delta V_{51}$ & -8.8148 \\
\hline$\Delta V_{52}$ & 0.4019 \\
\hline$\Delta V_{61}$ & 0.1820 \\
\hline$\Delta V_{62}$ & 1.9838 \\
\hline
\end{tabular}

Tabel 4.11. merupakan hasil bobot baru pada hidden layer pada iterasi pertama, hasil yang didapat masih jauh dari error minimum yang diharapkan yaitu 0 , sedangkan hasil dari bobot baru pada hidden layer dapat dilihat pada tabel 4.12 . 
Tabel 4.11. Hasil Bobot Baru Pada Output Layer

\begin{tabular}{|l|l|}
\hline \multicolumn{2}{|c|}{ Bobot Baru pada hidden layer } \\
\hline$\Delta W_{11}$ & -0.7645 \\
\hline$\Delta W_{12}$ & -0.6006 \\
\hline
\end{tabular}

Tabel 4.12 merupakan hasil bobot baru pada output layer pelatihan dengan iterasi pertama, hasilnya juga masih jauh dari error minimum yang diharapkan, hal ini dikarenakan masih pada iterasi pertama, untuk mencapai goal perlu dilakukan iterasi selanjutnya sampai goal ditemukan dengan nilai error yang dihasilkan 0 (nol), dari perhitungan output layer didapatkan nilai output sebesar 0,7830 dengan tingkat error sebesar -0,1161, sedangkan nilai target yang diinginkan adalah 1 agar Jaringan Syaraf Tiruan bisa mengidentifikasi kualitas bibit tanaman karet, dapat disimpulkan bahwa pada iterasi pertama goal belum mencapai target, dengan arti kata pada iterasi pertama Jaringan Syaraf Tiruan Belum belum bisa mengidentifikasi kualitas bibit tanaman karet, untuk itu masih perlu dilakukan iterasi berikutnya agar Jaringan Syaraf Tiruan bisa mengidentifikasi kualitas bibit tanaman karet.

4.4. Implementasi dan Hasil Pengujian Dengan

MATLAB R2015a

Pada Proses Pengujian ini dilakukan dengan mencoba 5 Arsitektur yang berbeda dengan tujuan untuk membandingkan hasil akurasi dari proses pengujian, berikut ini tabel 5.3 hasil pengujian dengan 5 arsitektur yang berbeda.

Tabel. 4.2. Hasil Data Uji Dengan 5 Arsitektur Yang

Berbeda

\begin{tabular}{|c|c|c|c|c|c|c|}
\hline \multirow{2}{*}{ SP } & \multirow{2}{*}{ TG } & \multicolumn{5}{|c|}{ ARSITEKTUR } \\
\cline { 3 - 7 } & & $\mathbf{6 1 5 1}$ & $\mathbf{6 1 0 1}$ & $\mathbf{6 5 1}$ & $\mathbf{6 3 1}$ & $\mathbf{6 2 1}$ \\
\hline 1 & 1 & 0.9999 & 0.8145 & 0.8435 & 0.6887 & 0.7876 \\
\hline 2 & 1 & 0.9999 & 0.8353 & 0.9759 & 0.8870 & 0.9813 \\
\hline 3 & 1 & 1.0000 & 0.8732 & 0.9833 & 0.8795 & 0.9867 \\
\hline 4 & 1 & 0.9998 & 0.5753 & 0.7155 & 0.6624 & 0.6129 \\
\hline
\end{tabular}

\begin{tabular}{|c|c|c|c|c|c|c|}
\hline 5 & 0.5 & 0.5000 & 0.5416 & 0.5524 & 0.5638 & 0.5063 \\
\hline 6 & 0.5 & 0.5000 & 0.5001 & 0.5686 & 0.6170 & 0.5056 \\
\hline 7 & 0.5 & 0.5000 & 0.5000 & 0.5024 & 0.5516 & 0.5054 \\
\hline 8 & 0.5 & 0.5000 & 0.5000 & 0.5014 & 0.6392 & 0.5056 \\
\hline 9 & 0.5 & 0.5000 & 0.5001 & 0.5411 & 0.6000 & 0.5070 \\
\hline 10 & 0.5 & 0.5000 & 0.5000 & 0.5062 & 0.5953 & 0.5018 \\
\hline 11 & 0.5 & 0.5000 & 0.5000 & 0.5015 & 0.6275 & 0.5056 \\
\hline 12 & 0.5 & 0.5000 & 0.8548 & 0.6864 & 0.5949 & 0.5137 \\
\hline 13 & 0.5 & 0.5000 & 0.5000 & 0.5015 & 0.6113 & 0.5056 \\
\hline
\end{tabular}

Tabel. 4.2. Hasil Data Uji Dengan 5 Arsitektur Yang Berbeda (Lanjutan)

\begin{tabular}{|c|c|c|c|c|c|c|}
\hline \multirow{2}{*}{ SP } & \multirow{2}{*}{ TG } & \multicolumn{5}{|c|}{ ARSITEKTUR } \\
\cline { 3 - 7 } & & $\mathbf{6 1 5 1}$ & $\mathbf{6 1 0 1}$ & $\mathbf{6 5 1}$ & $\mathbf{6 3 1}$ & $\mathbf{6 2 ~ 1}$ \\
\hline 14 & 0.5 & 0.5000 & 0.5000 & 0.5402 & 0.5690 & 0.5056 \\
\hline 15 & 0.5 & 0.5000 & 0.5000 & 0.5016 & 0.5812 & 0.5056 \\
\hline 16 & 0.5 & 0.5000 & 0.5000 & 0.5180 & 0.5909 & 0.5056 \\
\hline \multicolumn{2}{|c|}{ Akurasi } & $\mathbf{1 0 0 \%}$ & $\mathbf{6 8 . 7 5}$ & $\mathbf{8 7 . 5}$ & $\mathbf{8 1 . 2 5}$ & $\mathbf{8 7 . 5}$ \\
\hline
\end{tabular}

berikut ini grafik hasil pengujian dengan 5 pola arsitektur yang berbeda :

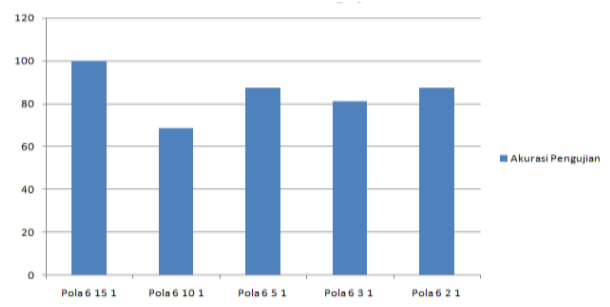

Gambar 5.15. Grafik Tingkat Akurasi Hasil Pengujian Dengan 5 Arsitektur

berikut ini tabel data aktual dan data hasil pengujian dengan menggunakan Arsitektur pola 6151 .

Tabel. 5.4. Hasil Data Uji Dengan Arsitektur Pola 6151

\begin{tabular}{|c|c|c|l|}
\hline $\mathbf{d k}$ & $\mathbf{T}$ & $\mathbf{H U}$ & \multicolumn{1}{|c|}{ Ket } \\
\hline 1 & 1.00 & 0.99 & Dknl \\
\hline 2 & 1.00 & 0.99 & Dknl \\
\hline 3 & 1.00 & 1.00 & Dknl \\
\hline 4 & 1.00 & 0.99 & Dknl \\
\hline 5 & 0.50 & 0.50 & Dknl \\
\hline 6 & 0.50 & 0.50 & Dknl \\
\hline 7 & 0.50 & 0.50 & Dknl \\
\hline
\end{tabular}




\begin{tabular}{|c|c|c|l|}
\hline 8 & 0.50 & 0.50 & Dknl \\
\hline 9 & 0.50 & 0.50 & Dknl \\
\hline 10 & 0.50 & 0.50 & Dknl \\
\hline 11 & 0.50 & 0.50 & Dknl \\
\hline 12 & 0.50 & 0.50 & Dknl \\
\hline 13 & 0.50 & 0.50 & Dknl \\
\hline 14 & 0.50 & 0.50 & Dknl \\
\hline 15 & 0.50 & 0.50 & Dknl \\
\hline 16 & 0.50 & 0.50 & Dknl \\
\hline
\end{tabular}

dengan tingkat akurasi hasil pengujian yang dilakukan terhadap bibit karet sebesar 100\%.

\section{Daftar Pustaka}

1. Z. Effendi, R. Ramli dan J.A. Ghani (2010). A Backpropagation Neural Network for Grading Jatropha curcas Fruits Maturity, American Journal of Applied Sciences 7. ISSN 1546-9236.

Berikut ini grafik perbandingan data aktual dengan data hasil pengujian :

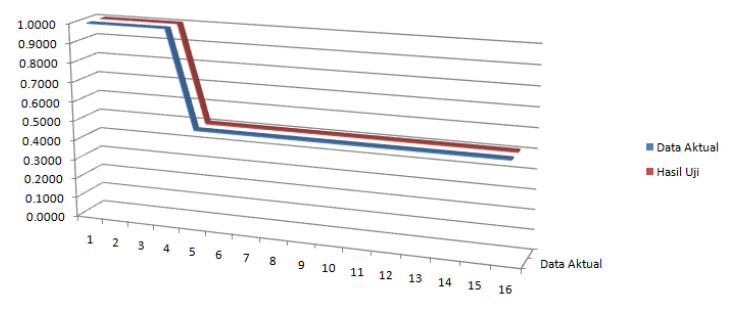

Gambar 4.16. Grafik Perbandingan Data Aktual Dengan Hasil Pengujian

\section{Kesimpulan}

Dari penelitian yang telah dilakukan dapat disimpulkan sebagai berikut :

1. Jaringan Syaraf Tiruan dengan metode Backpropagation dapat diterapkan untuk mengidentifikasi kualitas bibit tanaman karet, sesuai dengan ciri-ciri dari biji karet yang sudah diamati dan diukur secara manual.

2. Jaringan Syaraf Tiruan dengan metode Backpropagation menggunakan arsitektur pola 6151 lebih akurat dibandingkan dengan pola yang lain yaitu pola 6101 , pola 651 , pola 631 dan pola 621 .

3. Semakin Banyak Hidden Layer yang dibuat maka semakin bagus Jaringan Syaraf Tiruan dalam mengenali objek.

4. Semua sampel yang digunakan dalam pengujian dapat dikenali dengan baik oleh Jaringan Syaraf Tiruan

2. A.Suyantohadi, M.Hariadi, MH.Purnomo dan T.Morimoto (2010). Dynamic neural network model for identifying cumulative responses of soyban plant growth based on nitrogen fertilizer compositions, Australian Journal of Agricultural Engineering . ISSN 1836-9448.

3. Muhammad Asyhar Agmalaro, Aziz Kustiyo dan Auriza Rahmad Akbar (2013). Identifikasi Tanaman Buah Tropika Berdasarkan Tekstur Permukaan Daun Menggunakan Jaringan Syaraf Tiruan , Jurnal Ilmu Komputer Agri-Informatika .Vol 2 No.2. ISSN 2089-6026

4. Anggi Putriani (2012). Identifikasi Shorea Menggunakan Jaringan Syaraf Tiruan Propagasi Balik Resilient Berdasarkan Karakteristik Morfologi Daun , Departemen Ilmu Komputer, Institut Pertanian Bogor, 2012.

5. Rizki Tunjung Sari (2013). Perbandingan Metode Jaringan Syaraf Tiruan Backpropagation dan Algoritma Pencocokan Dalam Mengidentifikasi Kematangan Tomat Buah Berdasarkan Ciri Warna RGB , Fakultas Sains dan Teknologi, UIN Sunan Kalijaga, 2012.

6. Rizki Tunjung Sari (2013). Perbandingan Metode Jaringan Syaraf Tiruan Backpropagation dan Algoritma Pencocokan Dalam Mengidentifikasi Kematangan Tomat Buah Berdasarkan Ciri Warna RGB , Fakultas Sains dan Teknologi, UIN Sunan Kalijaga, 2012. 
7. Atris Suyantohadi, Mochamad Hariadi dan Mauridhi Hery Purnomo (2009). Identifikasi Pertumbuhan Tanaman Kedelai (Glycine max L) Dengan Pengaruh Pemberian Komposisi Pupuk Menggunakan Metoda Artificial Neural Network, AGRITECH, Vol. 29 No.4 November 2009.

8. I Putu Gede Budisanjaya (2013). Identifikasi Nitrogen dan Kalium Pada Daun Tanaman Sawi Hijau Menggunakan Matriks Co-Occurrence, Moments dan Jaringan Syaraf Tiruan, PPS. Universitas Udayana,Denpasar, 2013

9. Kadir, L.E. Nugroho, A.Susanto dan P.I. Santoso (2011). Neural Network Applications on Foliage Plant Identification, International Journal of Computer Applications (0975-8887) Vol. 29 No.9 September 2011

10. M.F.Andrijasa dan Mistianingsih (2010). Penerapan Jaringan Syaraf Tiruan Untuk Memprediksi Jumlah Pengangguran diProvinsi Kalimantan Timur Dengan Menggunakan Algoritma Pembelajaran Backpropagation, Jurnal Informatika Mulawarman Vol 5 No.1 Februari 2010.

11. C.S. Sumathi dan A.V. Senthil Kumar (2014). Neural Network basedPlant Identification using Leaf Characteristics Fusion, International Journal of Computer Applications (0975-8887) Volume 89 No.5, Maret 2014.

12. Dewi Puspitasari (2011). Identifikasi Jenis Shorea Menggunakan Jaringan Syaraf Tiruan Propagasi Balik Berdasarkan Karakteristik Morfologi Daun, Departemen Ilmu Komputer, Institut Pertanian Bogor.2011.

13. Jong Jek Siang (2009). Jaringan Syaraf Tiruan dan Pemrogramannya Menggunakan MATLAB. ISBN.978-979-29-0493-2.
14. Tumpal H.S. Siregar dan Irwan Suhendry(2013). Budi Daya Dan Teknologi Karet. ISBN 978-979002-592-9.

15. Tim Penulis PS (2013). Panduan Lengkap Karet. ISBN 978-979-002-233-6. 